\title{
PENERAPAN TEKNIK KASAB ACEH PADA PRODUK SEPATU WANITA DEWASA
}

\author{
Zulfikar ${ }^{1}$ (Zul.fikar6713@gmail.com, Universitas Sebelas Maret) \\ Adji Isworo Josef ${ }^{2}$ (adjiisworo@staff.uns.ac.id, Universitas Sebelas Maret) \\ Ratna Endah Santoso 3 (cezaraesa@gmail.com, Universitas Sebelas Maret)
}

\begin{abstract}
Indonesia has many cultural heritages, one of them are the techniques of traditional textile such as Kasab from Aceh. The purpose of this design is to invent a brand new product in ethnic women shoes diversities with edgy style. The designs were made based on the aesthetic value and also new material as an innovation for the oldest Kasab which had been existed. The results of this creative process were 6 designs of shoes, all designs are applied on the upper and 5 amongst them were produced as 2 pairs of flat shoes and 3 pairs of wedges.
\end{abstract}

Keyword: Kasab, Shoes, Surface design, Upper, Edgy Style.

\begin{abstract}
ABSTRAK
Indonesia memiliki banyak warisan budaya, salah satunya yaitu teknik Kasab yang berasal dari Aceh. Tujuan perancangan adalah menciptakan produk baru untuk keberagaman sepatu etnik untuk wanita dewasa dengan karakter fashion edgy style. Pengolahan visual dirancang dengan mempertimbangkan nilai estetis dan menggunakan bahan baru sebagai potensi inovasi Kasab yang sudah ada. Proses kratif dengan metode teknik ini menghasilkan 6 desain, seluruh desain diaplikasikan pada upper dan 5 diantaranya direalisasi pada 2 sepatu flat dan 3 sepatu wedges.
\end{abstract}

Kata Kunci : Kasab, Sepatu, Desain permukaan, upper, Edgy.

\section{PENDAHULUAN}

Sepatu mengalami perkembangan

jenis yang berlandaskan fungsi dari pemakaiannya. Industri sepatu semakin bersaing untuk mengembangkan produknya, sepatu sebagai salah satu kebutuhkan yang mampu menunjang penampilan bagi para wanita. Terdapat beberapa jenis alas kaki wanita, yaitu: Flat shoes 1-4 cm, Wedges shoes 5-9 cm, Heels $5-15 \mathrm{~cm}$. Jenis sepatu tersebut banyak digunakan oleh wanita dalam berbagai kegiatan. Menurut Nurani (2013) Dewasa ini fungsi sepatu semakin meningkat, dimana sepatu menjadi sebuah simbol dari status sosial dan memiliki tampilan menarik bagi wanita. Produk sepatu wanita memiliki berbagai perkembangan desain dari waktu ke waktu secara estetis bagi produk sepatu. Bahan yang digunakan juga melalui tahapan kreatif dari waktu ke waktu, diantaranya; Kulit, Sintetis, dan juga Tekstil lain pada umumnya.

Bahan tekstil tradisional juga dapat digunakan pada sepatu seperti yang ditampilkan pada produk sepatu CV.Warisan 
Nusantara Indonesia. Perusahaan tersebut bergerak dibidang produksi sepatu yang memiliki brand "The Warna" (Warisan Nusantara). Produk sepatu perusahaan tersebut menggunakan tekstil tradisional yang dihasilkan dari beberapa teknik tradisi, diantaranya: Tenun Songket, Batik, Jumputan, dan printing (Istilah tekstil bermotif tertentu tanpa melalui proses desain tekstil permukaan atau desain tekstil struktur, melainkan proses motif tekstil dengan cara cetak). Hal ini sesuai dengan salah satu misi perusahaan, maka pengembangan desain sepatu dapat menggunakan beberapa teknik tekstil tradisi yang berada di Indonesia.

Kasab merupakan salah satu teknik tradisi untuk pembuatan tekstil tradisional dari ujung barat Indonesia, Provinsi Aceh. Kasab adalah teknik pembuatan motif diatas kain, Kasab termasuk dalam kategori desain tekstil permukaan. Teknik tersebut pada umumnya diaplikasikan pada tirai, sarung bantal, pakaian adat dan lain sebagainya. Bahan utama dalam teknik ini adalah benang emas yang disulam diatas kain bludru. Warna khas dari motif Kasab tradisi adalah emas dan perak. Kasab sangat menarik diterapkan pada produk sepatu, yaitu melalui tekstur yang dihasilkan menjadi daya tarik tersendiri.

Berdasarkan penjabaran di atas muncul kemungkinan untuk menerapkan teknik Kasab pada sepatu wanita dewasa. Adapun terdapat pula permasalahan yang akan dihadapi pada perancangan ini, yaitu: pertama, bagaimana menerapkan teknik tradisi Kasab pada permukaan tekstil yang akan memvisualkan sepatu menjadi sebuah produk yang modern. Kedua, menghasilkan produk sepatu The Warna yang mengikuti zaman namun terdapat unsur etnik didalamnya. Hal ini menjadi fokus permasalahannya adalah bagaimana penerapan Kasab Aceh sebagai teknik dalam perancangan desain tekstil permukaan pada produk sepatu wanita dewasa.
Tujuan perancangan adalah menciptakan produk baru untuk keberagaman sepatu etnik. Ide visual produk yang ditawarkan adalah sepatu kasual wanita dewasa yang berkarakter edgy style. Sumber ide ini mempertimbangkan keterkaitan Kasab dengan produk sepatu etnik, yaitu Kasab merupakan teknik tradisi Aceh yang menjadikan produk sepatu tersebut memvisualkan etnik Aceh. Manfaat perancangan ini yaitu menajag an melestarikan kebudayaan Indonesia melalui kreatifitas dengan menambah keberagaman produk sepatu etnik. Straregi yang dilakukan berupa pengumpulan data melalui studi literatur, observasi dan wawancara. Observasi dan wawancara dilakukan di dua tempat yaitu CV.Warisan Nusantara Indonesia sebagai lokasi dan narasumber mengenai sepatu etnik. Desa Lagang Kecamatan Mila - Aceh menjadi lokasi observasi dan para pengrajin Kasab tradisi sebagai narasumber mengenai Kasab.

\section{Kasab Tradisi Aceh}

Kasab adalah kerajinan sulaman benang emas di wilayah Aceh atau sering disebut dengan "Kasab Aceh". Kerajinan ini pertama sekali muncul di daerah pemukiman yaitu kecamatan Meuraxa Ulee Lheue dari keturunan sebuah keluarga Teuku. M. Yusuf di kampung Dayah Glumpang Ulee Lheue di kota Banda Aceh, Harun (2016). Menurut Leigh (1989) bentuk-bentuk motif dengan penggambaran yang realis dari bentuk manusia dan hewan sangat jarang digunakan untuk menghiasi benda-benda kerajinan. Motif-motif yang digunakan pada umumnya merupakan stilisasi dari tumbuh-tumbuhan, antara lain: daun, kelopak, bunga, buah atau suluran-suluran. Selain motif tumbuhtumbuhan ada juga yang dikombinasikan dengan motif-motif geometris. Pemilihan motif dengan bentuk tumbuh-tumbuhan dan benda alam berkaitan dengan kepercayaan 
atau agama orang-orang Aceh yaitu agama Islam.

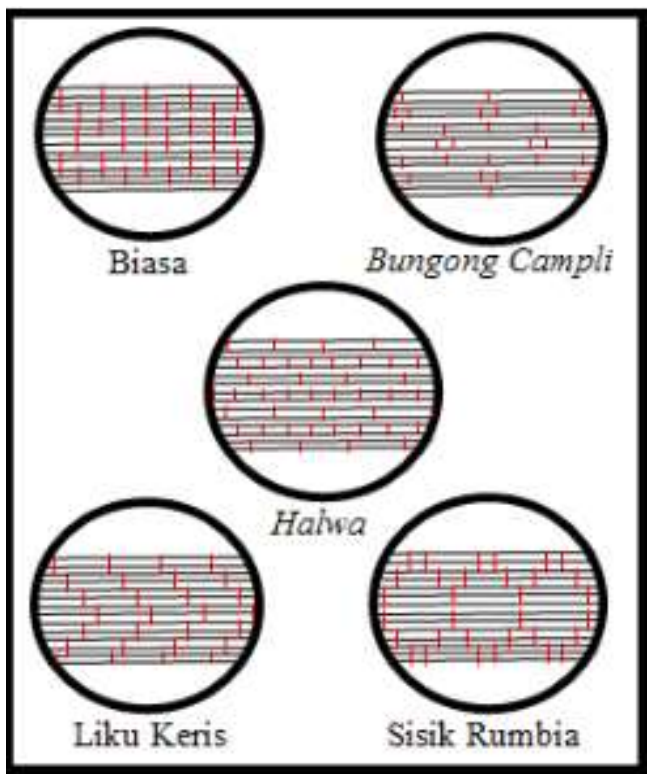

Gambar 1. Jenis jahitan teknik Kasab Pesisir selatan Aceh Sumber: Leight, 1989

Menurut Leigh (1989) terdapat 2 jenis Kasab tradisi Aceh, diantaranya: Pertama, Kasab pesisir selatan Aceh, jenis Kasab ini memiliki ciri khas motifnya yang sangat beragam. Teknik ini bisa membuat berbagai motif yang diinginkan, karena benang emas yang dipakai dapat diaplikasikan diberbagai motif. Jenis Kasab ini dapat ditemukan di pesisir selatan Aceh, terdiri dari suku Aneuk Jamee dan suku Alas. Jenis jahit timbul datar (flat Couching) Kasab pesisir selatan, diantaranya:

Jahitan biasa yaitu jahitan benang katun sebagai penguat benang emas atau perak. Jahitan yang berbentuk pola seperti susunan batu bata pada Kasab pesisir selatan Aceh. Jahitan bungong campli yaitu jahitan benang katun sebagai penguat benang emas atau perak. Jahitan yang berbentuk pola seperti bunga pohon cabai pada Kasab pesisir selatan Aceh. Jahitan iris halwa yaitu jahitan benang katun sebagai penguat benang emas atau perak. Jahitan yang berbentuk pola seperti irisan halwa pada Kasab pesisir selatan Aceh. Jahitan liku keris yaitu jahitan benang katun sebagai penguat benang emas atau perak. Jahitan yang berbentuk pola seperti balok patah pada Kasab pesisir selatan Aceh. Jahitan sisik rumbia yaitu jahitan benang katun sebagai penguat benang emas atau perak. Jahitan yang berbentuk pola persegi delapan, seperti sisi batang pohon rumbia yang di potong pada Kasab pesisir selatan Aceh (Wawancara dengan syamsiah, 10 Desember 2017).

Kedua, Kasab pesisir timur Aceh, jenis Kasab ini memiliki ciri khas yang unik dari ketebalan teksturnya. Tekstur timbul tersebut terbuat dari kertas karton yang ditutup dengan benang Emas. Kasab ini dapat ditemukan di pesisir timur Aceh yang terdiri dari suku Aceh dan Melayu. Teknik ini menyulam benang emas di atas karton, dimana karton tersebut berfungsi sebagai isi kasab untuk menimbulkan tekstur yang unik. Benang emas tersebut dikuatkan dengan benang jahit biasa, ini merupakan proses pembuatan Kasab Aceh pesisir timur. Proses pembuatan Kasab pesisir timur aceh sedikit berbeda, yaitu setelah kain dasar dalam keadaan kencang, kemudian menyusun kertas karton terlebih dahulu pada kain tersebut.

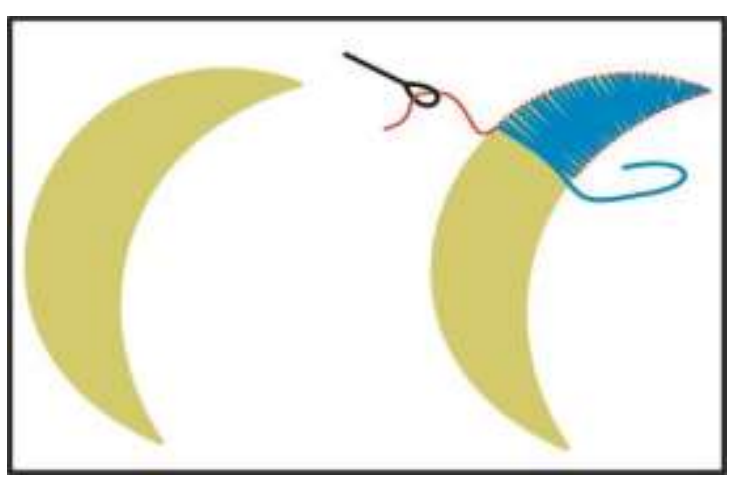

Gambar 2. Jahitan teknik Kasab pesisir timur Aceh Sumber: Leight, 1989

\section{Sepatu wanita dan perkembangannya}

Sepatu adalah suatu jenis alas kaki footwear - istilah sepatu pada jenis alas kaki yang terdiri dari bagiannya yang menjadi satu kesatuan - yang biasanya terdiri bagian-bagian sol, hak, kap, tali, dan lidah. Sepatu yang 
terbuat dari kanvas atau kulit menutupi semua bagian mulai dari jari jemari, punggung kaki hingga bagian tumit, Balai Pegembangan Industri Persepatuan Indonesia - BPIPI (2017). Alas kaki merupakan salah satu elemen fashion yang berfungsi untuk menunjukkan kelas sosialnya. Ornamen atau motif pada alas kaki sangat menunjang kepercayaan diri bagi pemakai. Fungsi motif pada alas kaki tersebut terlihat sederhana atau bahkan menjadi pusat perhatian. Menurut Nurani (2013) jenis sepatu heels banyak digunakan oleh wanita pada acara resmi atau acara besar lainnya. Dunia fashion saat ini semakin berkembang, sehingga menjadikan sepatu salah satu kebutuhan primer bagi wanita untuk menunjang penampilannya.

\section{PENGEMBANGAN DESAIN}

Pengembangan desain sepatu ini diarahkan menjadi produk massal dengan target pasar wanita dewasa usia 20 - 40 tahun. Produk yang dibutuhkan harus memiliki unsur etnik didalamnya. Etnik yang menjadikan simbol identitas kearifan lokal negara Indonesia khususnya Aceh. Hal ini menjadi acuan utama untuk merancang desain motif pada produk sepatu. Namun, produk yang akan dirancang akan terlihat modern sehingga mampu bersaing ditingkat nasional maupun international. Maka dari itu produk sepatu divisualkan secara modern dan terkesan etnik didalam motifnya. Mengutamakan kenyamanan pemakai karena desain sepatu yang dirancang untuk jenis casual.

Motif yang akan didesain terkesan santai, oleh sebab itu sepatu yang dirancang berupa flat shoes dan wedges shoes. Sisi modern dalam karya ini akan terlihat dari mode sepatu yang dirancang. Produk pada karya ini menggunakan denim sebagai bahan upper dan tali cord dan tali elastis sebagai bahan Kasab untuk memunculkan karakter edgy. Titik berat visual perancangan ini adalah penerapan teknik Kasab tradisi Aceh sebagai ciri khas etnik pada motif di permukaan tekstil tersebut. Hal ini menjadi fokus pada sifat hingga warna bahan pada proses produksi tekstil.

Perancangan sepatu etnik ini menggunakan teknik Kasab pesisir selatan Aceh dengan jenis jahitan biasa dan jahitan halwa. Selain itu juga menggunakan teknik Kasab pesisir timur Aceh dikarenakan teknik ini memiliki ciri khas dari tekstur yang ditimbulkan. Tekstur yang dihasilkan Kasab dapat dikategorikan tekstur raba. Tekstur digolongkan menjadi dua yaitu tekstur raba dan tekstur lihat, tekstur raba yaitu tekstur yang dapat dirasakan melalui indera peraba misalnya ujung jari, Affanti (2008). Kedua teknik ini termasuk seni kriya tekstil, dikarenakan sepatu ini akan diproduksi dengan bahan serat dan dikerjakan dengan manual. Seni kriya tekstil adalah karya seni kriya yang berbahan dasar serat/kain, baik berupa kain yang ditenun, dirajut, diikat, di pres maupun dengan berbagai cara lainnya, Bodiyono (2008).

\section{METODE PERANCANGAN}

\section{a. Pendekatan perancangan.}

Metode perancangan yang digunakan dalam merancang produk sepatu etnik ini adalah desain engineering (teknik). Urutan kegiatan dalam desain engineering dapat diuraikan dalam tahapan sebagai berikut: (1) Tahap Fensibility study (Studi kelayakan), yaitu menentukan konsep yang layak melalui studi kelayakan. (2) Tahap Preliminary Design (Desain Awal), yaitu sebagai awal ddari mendesain melaui pemilihan dan pengembangan konsep yang terbaik. (3) Tahap Detailed Design (Desain yang rinci), yaitu merinci secara detail dari sebuah uraian teknik mengenai konsep tersebut. (4) Tahap Planning (Perencanaan), yaitu menilai dan merubah konsep untuk disesuaikan dengan kebutuhankebutuhan produksi, distribusi, konsumsi, dan penyisihan produk. (5) Tahap Feed Back 
(Umpan balik/reaksi), yaitu sebagai umpan balik apabila terjadi kekeliruaan, Rizali (2012).

Proses perancangan (mendesain) dimulai tahap 1 dengan memasukkan data informasi. Sekumpulan gagasan alternatif ini bagi sebuah desain yang cepat diketahui (dikenal). Tahap 2 adalah memilih salah satu dari alternatif untuk dikembangkan lebih lanjut. Apabila desain ini telah mencapai titik memuaskan untuk kemudian dipecah secara mendetail pada tahap 3. Selanjutnya melalui kerja paralel seandainya dapat dilakukan untuk mempercepat proses pada tahap 4. Proses tersebut tidak akan berjalan dengan baik bila asumsi-asumsi yang mendasari pemilihan desain semua ternyata keliru (tahap 5) ketika tahapan detail dikerjakan, Rizali (2012). Tahapan proses perancangan diawali dengan identifikasi masalah. Tahapan ini merupakan pengenalan terhadap masalah dan pengetahuan tentang kebutuhan yang harus terpenuhi. Tahap selanjutnya analisa perancangan produk, yaitu kajian teoritik dan tinjauan empirik. Hasil tahapan tersebut memunculkan gagasan awal sebagai bagian dari tahap proses kreatif. Hasil desain terpilih dari proses kreatif akan dilakukan uji coba produk.

\section{b. Analisis Perancangan}

Berdasarkan fokus permasalahan di atas muncul dua pembahasan dalam perancangan produk sepatu dengan sumber ide penerapan Kasab Aceh. Pertama, visual yaitu mewujudkan motif kekinian yang akan diaplikasikan pada produk sepatu dengan menggunakan teknik Kasab tradisi Aceh. Beberapa aspek didalamnya seperti; aspek estetis, aspek teknik dan aspek bahan. Hal ini sangat perlu diperhatikan untuk mempertahankan khas Kasab tradisi. Kedua, desain produk yaitu mewujudkan produk sepatu kasual untuk wanita dewasa. Beberapa hal yang perlu diperhatikan dalam desain produk yaitu; ciri khas teknik Kasab Aceh dan karakter fashion untuk menentukan desain produk sepatu.

Desain motif dalam perancangan ini tidak menggunakan motif tradisional Aceh, melainkan pengembangan desain motif dari sumber ide motif yang dihasil dari Kasab tradisi Aceh. Adapun motif dapat mewujudkan suatu produk sepatu kasual wanita dewasa. Karakter fashion untuk desain produk sepatu ini yaitu karakter edgy Style. Menurut Mandasari (2017), edgy style merupakan istilah dalam fashion yang digunakan oleh para desainer untuk menggambarkan suatu karakter desain. Karakter edgy style dalam desain adalah karakter fashion yang inovatif, orisinil, unik dan menerobos batas-batas konvensional untuk menawarkan hal-hal baru. Hal ini mewujudkan produk sepatu kasual edgy untuk wanita dewasa.

\section{c. Strategi pemecahan masalah}

Berdasarkan Analisa permasalahan diatas, muncul sejumlah strategi dalam perancangan ini. Pertama, pengembangan desain motif dari sumber ide motif yang dihasilkan dari Kasab tradisi Aceh. Perkembangn tersebut dengan cara mengolah motif kontemporer untuk mewujudkan visual kekinian pada produk sepatu. Kontemporer yang di maksud adalah suatu kebaharuan, yaitu tidak mengikuti dan berada pada ketentuan tradisi. Mengolah motif tersebut memperhatikan nilai estetis pada unsur bidang dan unsur warna yang digunakan. Mewujudkan strategi tersebut berhubungan erat dengan bahan. Bahan yang digunakan mampu memvisualkan suatu produk sepatu kasual. Tidak menggunakan bahan kulit dan sintetis yang kerap digunakan pada produk sepatu. Menggunakan karakteristik bahan yang kuat dan kokoh, seperti Denim. Selain itu akan menggunakan tali yang dapat mengikuti pola motif dari desain yang diinginkan. Kedua, desain produk sepatu dibuat dengan mempertimbangkan penerapan teknik Kasab 
tradisi Aceh. Teknik Kasab yang terapkan yaitu Kasab tradisi pesisir selatan Aceh dan Kasab tradisi pesisir timur Aceh. Menggunakan dua Kasab tersebut sebagai teknik penerapan motif pada tekstil yang akan menjadi bahan bahan produksi sepatu. Pengembangan desain motif akan mengikuti aturan dari proses pembuatan motif dari kedua teknik Kasab tersebut. Seperti yang telah dijelaskan sebelumnya, dari kedua jenis Kasab tersebut memiliki ciri khasnya masing-masing. Aturan yang telah ditentukan untuk bahan motif pada proses teknik Kasab pesisir selatan yaitu tali sebagai unsur motif mampu menyesuaikan betuk motif. Bahan untuk motif yang telah ditentukan pada proses teknik Kasab pesisir timur yaitu tali yang mampu menyesuaikan bentuk isen-isen sebagai isi yang menimbulkan tekstur pada motif.

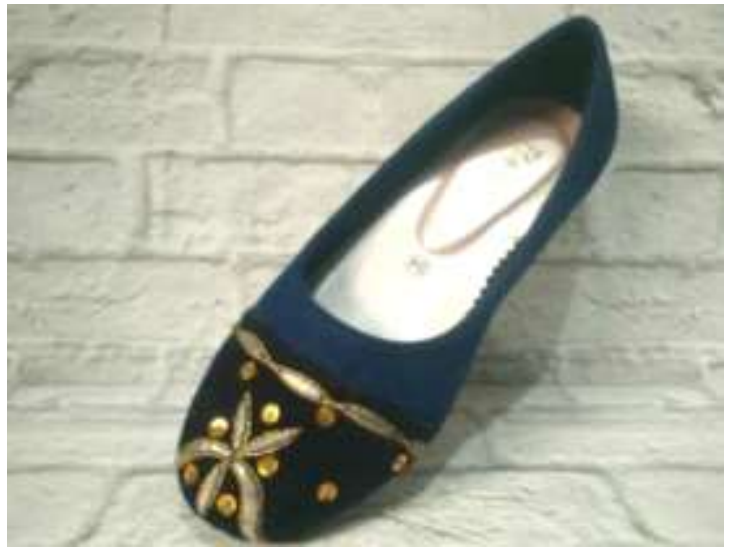

Gambar 3. Hasil uji coba ketahanan jahitan kasab tradisi. Sumber: Zulfikar, 2017

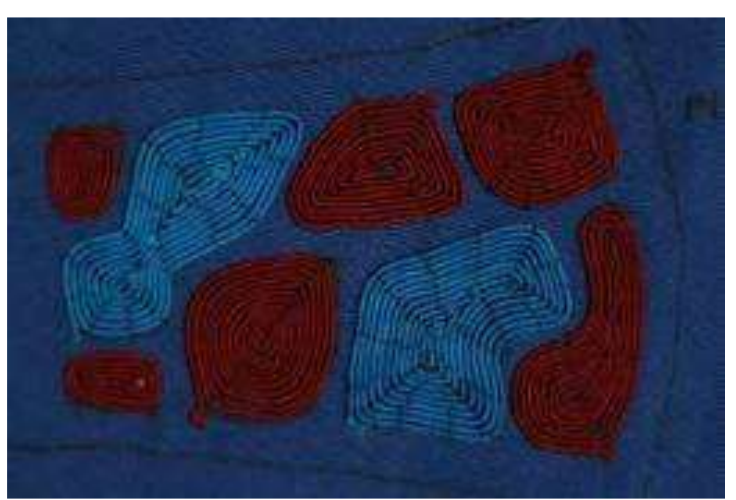

Gambar 4. Hasil uji coba bahan. Sumber: Zulfikar, 2018
Ketiga, uji coba visual dilakukan untuk mencari karakter edgy style pada mode sepatu wanita dewasa. Uji coba tersebut dilakukan juga untuk menemukan beragam motif yang dapat dihasilkan dengan penerapan teknik Kasab. Acuan mode sepatu yang diuji yaitu sepatu kasual dari jenis flat shoes dan wedges shoes. Ide untuk visual motif adalah kearifan lokal yaitu pemandangan indah yang dimiliki Negara Indonesia, seperti pemandangan sawah terasering, pemandangan sungai, pemandangan bawah laut, dan bentuk geometris yang erat dari nuansa pemandangan tersebut.

\section{KONSEP PERANCANGAN}

Konsep perancangan ini adalah bagaimana memanfaatkan warisan budaya Indonesia berupa teknik Kasab tradisi Aceh menjadi sumber ide pengembangan produk sepatu etnik. Merancang produk sepatu dengan teknik Kasab mampu menyesuaikan pola yang diinginkan, serta mudah bila dikerjakan secara manual. Berdasarkan penjelasan sebelumnya, Kasab merupakan salah satu teknik desain tekstil permukaan. Menurut Rizali (2012) desain tekstil permukaan ialah membuat hiasan atau motif tertentu pada kain namun hanya pada permukaannya saja. Dapat pula ditafsirkan membuat pola motif di atas kain. Desain tekstil permukaan termasuk dalam salah satu klasifikasi desain tekstil.

Berdasarkan studi yang telah dilakukan dalam pengumpulan data, terdapat beberapa aspek yang harus dipertimbangkan dalam melakukan perancangan penerapan teknik Kasab pada sepatu. Aspek estetis dari desain ini adalah bagaimana memainkan karakter visual motif dari teknik Kasab tanpa mengurangi ciri khas teknik tradisi tersebut. Desain ini tidak memakai motif tradisional Aceh yang dikerjakan dengan teknik Kasab pada umumnya. Motif yang dirancang merupakan inovasi baru berupa motif 
kontemporer. Memvisualkan kearifan lokal kedalam motif melalui teknik tersebut. Perancangan ini akan memunculkan visual edgy style dan terlihat tradisional dari jahitannya. Hal ini yang diperhitungkan dalam menunjang aspek estetis adalah simbol dan warna. Arahan simbol yang menginspirasi untuk motif pada perancangan ini yaitu beberapa bentuk geometris, flora dan suasana alam. Suasana alam tersebut dari sudut padang dataran yang tiggi. Adapun arahan simbol tersebut sesuai ketentuan Kasab tradisi Aceh yaitu tidak memakai simbol makluk hidup seperti yang dipercayai oleh masyarakat Aceh yang beragama Islam. Menurut Harun (2016), Agama Islam yang mereka percayai terdapat larangan-larangan dalam penggambaran makhluk hidup seperti manusia dan hewan sebagai sumber ide visual karya. Adapun arahan warna yang menginspirasi pada perancangan ini adalah warna-warna yang akan memvisualkan simbol tersebut.

Teknik yang digunakan dalam pengembangn desain ini adalah Kasab tradisi Aceh. Pemilihan teknik ini dikarenakan ingin mempertahankan etnik dan karakter kriya didalam produk. Kelebihan dari penggunaan teknik Kasab tradisi yaitu tekstur-tekstur yang dihasilkannya dan lebih luwes (ekspresif) dari sulaman. Tekstur tersebut timbul melalui tali utama sebagai aspek bahan pembuatan motif diatas permukaan kain. Tali utama yang digunakan pada produk ini yaitu tali elastis, tali cord (pada Kasab tradisi Aceh pesisir selatasn) dan Benang denim (pada Kasab tradisi Aceh pesisir timur). Adapun tekstur yang dimiliki oleh produk ini termasuk kedalam kategori tekstur raba seperti yang telah dijelaskan sebelumnya. Hasil motif dari teknik ini tidak akan ada jahitan yang sama persis dalam setiap pengulagannya sehingga dapat memunculkan karakter yang diinginkan, karena Kasab termasuk teknik kriya desain tekstil permukaan. Bahan yang digunakan dalam pembuatan upper sepatu dalam perancangan ini adalah kain denim. Kain denim merupakan bahan yang dapat menunjang visual karakter edgy style pada perancangan ini. Selain itu, bahan yang digunakan dalam pembuatan motif dengan teknik Kasab adalah Tali elastis, tali cord, dan benang jahit khusus untuk kain denim. Bahanbahan tersebut merupakan bahan yang dapat menunjang visual jenis sepatu kasual. Perancangan ini berfungsi sebagai wadah untuk melestarikan warisan budaya Aceh. Gaya atau karakter yang kuat dari perancangan ini adalah tekstur yang dimiliki oleh Kasab dan secara visual motifnya terlihat dikerjakan dengan manual. Hasil dari perancangan ini dapat mengenalkan kepada masyarakat dari potensi budaya Aceh yang dimiliki negara Indonesia melalui produk sepatu.

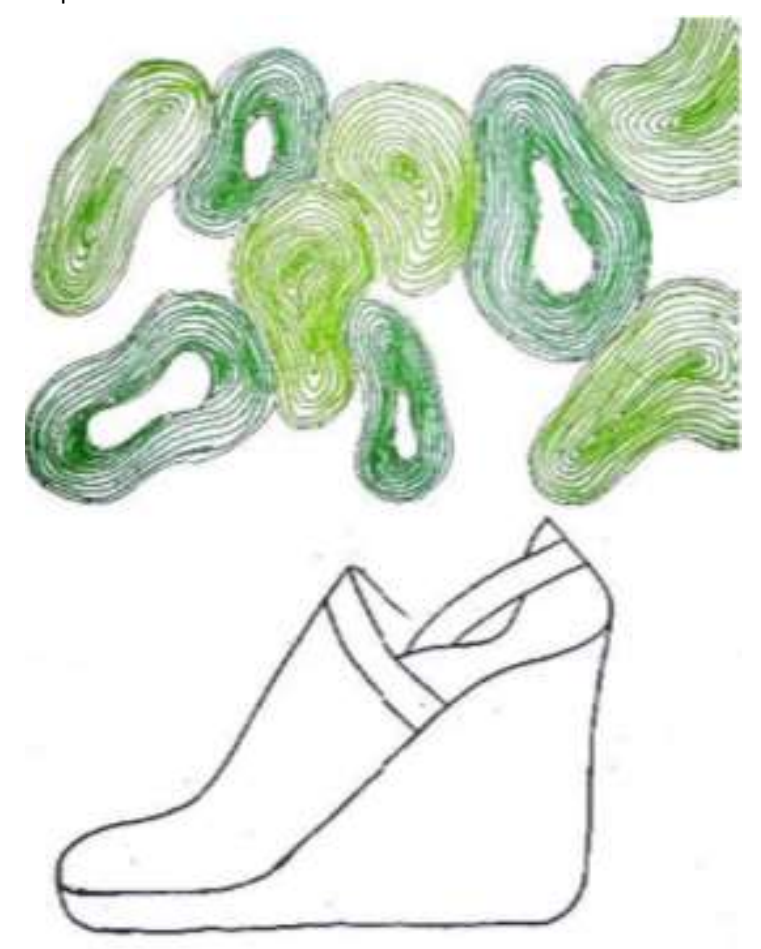

Gambar 5. Hasil uji visual motif dan produk. Sumber: Zulfikar, 2018

\section{VISUALISASI}

Teknik produksi upper menggunakan Kasab pesisir timur dan pesisir selatan Aceh. Tali cord dan tali eslastis diterapkan dengan Kasab pesisir selatan, yaitu menyulam tali 
tersebut mengikuti motif yang diinginkan. Benang katun dan benang bordir diterapkan dengan Kasab pesisir timur, yaitu menyulam benang tersebut mengikuti isen-isen yang diinginkan pada karton yang telah direkatkan terlebih dulu pada permukaan kain. Kain yang digunakan terlebih dulu dibentangkan pada spanram, dan dikaitkan menggunakan paku payung. Permukaan kain denim harus bersifat sangat kencang sebelum melanjutkan pada proses Kasab. Sebelum memasang kain pada spanram terlebih dahulu menulis pola upper pada permukaan denim. Kemudian menulis motif pada pola tersebut dengan menggunakan pena khusus untuk permolaan sepatu (White pen). Menggunakan pena tersebut akan mengurangi terlihatnya goresan saat produk sepatu telah diproduksi.

Setelah melakukan serangkaian studi, maka perancangan ini berhasil memvisualisasikan 6 upper sepatu dari 6 desain. Produk sepatu yang diproduksi 5 produk dari 6 desain yang terpilih, diantaranya 2 desain flat shoes dan 3 desain wedges shoes. Dengan ukuran rata-rata wanita Indonesia, yaitu 37, 38, dan 39. Berikut ini adalah hasil dari visualisasi perancangan penerapan Kasab tradisi Aceh pada sepatu wanita dewasa.

Hasil produk desain I "Seumeuloh Canggang" (Memandang dari ketinggian). Hal yang dimaksud adalah melihat fenomena dari ketinggian, yaitu menangkap situasi atau suatu pemandangan dari dataran tinggi. Pemandangan yang dimaksudkan ialah Kota. Pemandangan kota berupa gedung-gedung sebagai objek pandangan, ukuran tinggi gedung dari jarak pandang tersebut sama rata terlihat secara fiksi. namun gedung terlihat berbeda dari luas sebagai ruang-ruangnya. Ruang yang dimiliki oleh setiap gedung secara visual terlihat sama yaitu bentuk-bentuk persegi. Teknik pada produk ini adalah Kasab pesisir selatan Aceh. Ukuran 37 dengan soul $2,15 \mathrm{~cm}$, jenis sepatu flat shoes D'orsay inform ballet. Bahan upper yang digunakan yaitu denim, benang jahit denim, tali cord, tali elastis.

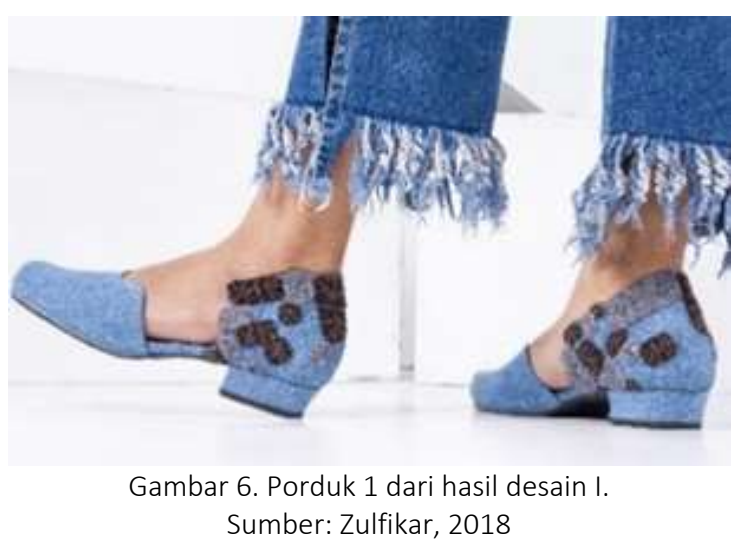

Hasil produk desain II "Blang" (Sawah), Sawah merupakan tempat bercocok tanam sumber bahan pangan. sawah termasuk wilayah yang luas atau dominan didaratan negara Indonesia. Sawah dari Sabang hinga Merauke, memiliki bentuk yang indah bila diamati dari sudut pandang berbeda, yaitu jarak yang mampu menjangkau pemandangan sawah serta bentuk keindahan yang dimilikinya. Contohnya melihat pemandangan sawah dari dataran tinggi secara visual sangat berbeda jika berada didalam hamparan sawah. Motif-motif yang tercipta dari sawah berbedabeda, seperti sawah penyumblingan di dataran rendah dengan sawah terasering yang terkenal di Bali. Teknik pada produk ini adalah Kasab pesisir selatan Aceh. Ukuran 38 dengan tinggi hak $10 \mathrm{~cm}$, jenis sepatu wedges shoes D'orsay sling back inform pointed toe. Bahan upper denim, benang jahit denim, tali cord, tali elastis. 


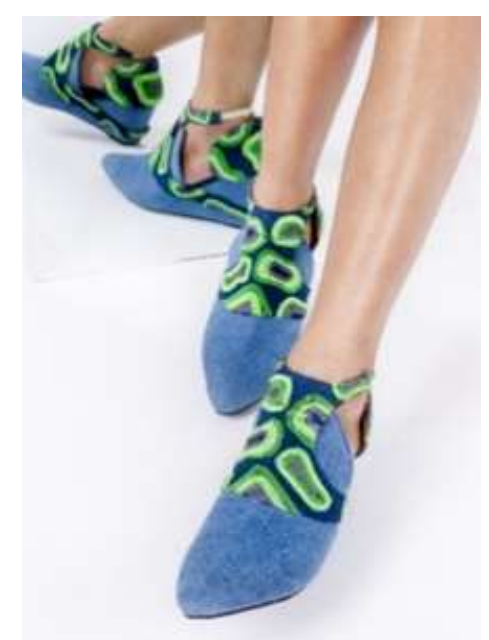

Gambar 7. Porduk 2 dari hasil desain II. Sumber: Zulfikar, 2018

Hasil produk Desain III "Cahya Langet" (Cahaya langit). Cahaya langit dalam pemahaman ini adalah seluruh benda ruang angkasa yang mampu memancarkan cahayanya hingga diterima oleh penglihatan manusia. Benda ruang angkasa seperti Bulan dan Bintang. Fenomena tersebut terjadi pada malam hari. Bulan dan Bintang memiliki cahaya yang bersifat lembut, sehingga mampu diterima langsung oleh indera penglihatan. Kelembutan menimbulkan rasa nyaman, sehingga manusia ingin melihat fenomena tersebut pada waktu malam hari. Teknik upper yang digunakan adalah Kasab pesisir selatan Aceh. Ukuran 39 dengan tinggi hak 7,6 cm. Jenis sepatu wedges Shoes D'orsay inform oval. Bahan upper yang digunakan denim, benang jahit denim, tali cord, tali elastis.

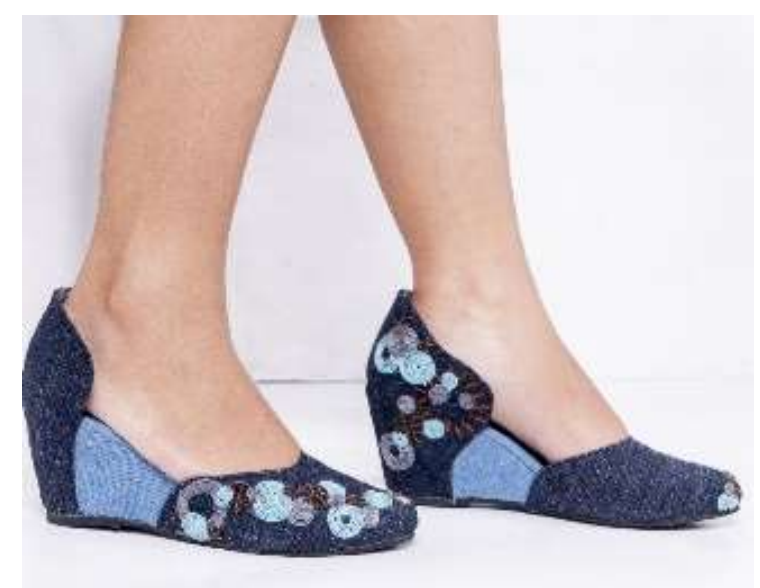

Gambar 8. Porduk 3 dari hasil desain III. Sumber: Zulfikar, 2018
Hasil produk Desain IV "Bungong Kareung Samudra" (Bunga Karang Samudera). Karang yang berada dibawah laut secara visual memiliki keindahan seperti bunga. Laut samudera memiliki alam bawah laut yang sangat indah. Hal ini yang dimaksud dengan bunga karang samudera adalah keindangan pemandangan alam bawah laut samudera, Seperti film kartun Spongebob memunculkan visual bunga yang menjadi keindahan khas di bawah laut. Kartun tersebut menjadi sumber inspirasi desain motif pada karya ini. Karakter khas bunga pada film tersebut ditampilkan lucu dan unik tidak heran anak kecil suka dengan visual bunga tersebut. Teknik pada produk ini adalah Kasab pesisir selatan Aceh. Ukuran sepatu 39 dengan soul 0,50 cm, jenis sepatu flat shoes D'orsay inform pointed. Bahan upper yang digunakan yaitu denim, benang jahit denim, tali cord, tali elastis.

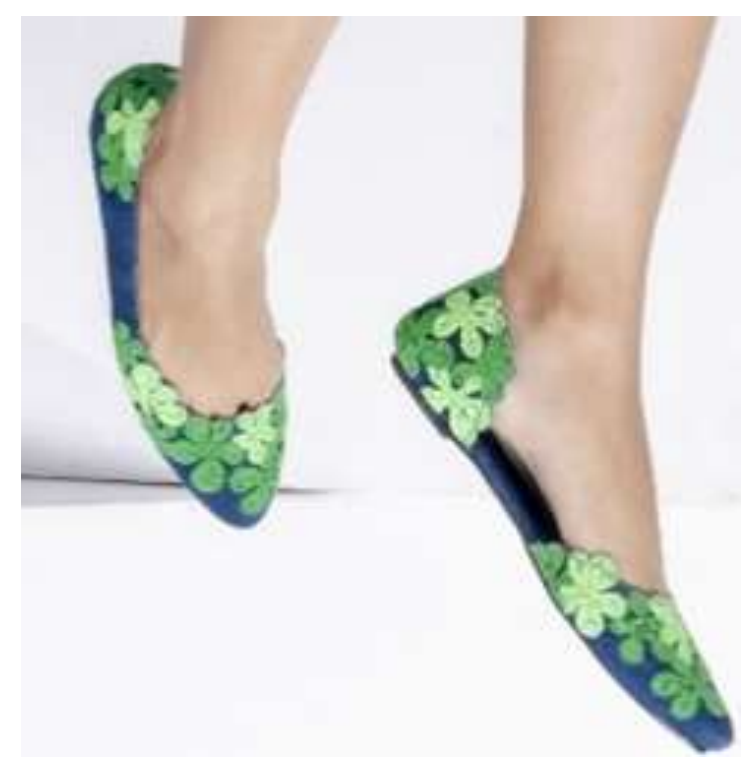

Gambar 9. Porduk 4 dari hasil desain IV. Sumber: Zulfikar, 2018

Hasil produk Desain V "Keneubah Pusaka" (Peninggalan Pusaka). Pusaka dalam pemahamannya fisik adalah harta benda. Banyak pusaka nenek moyang berupa tanah dan emas. Pusaka tersebut sebagai bekal untuk generasi mereka. Tanah sangat berinilai 
dari waktu ke waktu, sedangkan emas memiliki harga yang tinggi dan bersifat mewah. Tanoeh wareh (Tanah warisan) menjadi hal penting saat pembagian, serta pemetaan sebagai penentu hasil dari pembagian. Maka tanah dan emas tidak dapat dipisahkan sebagai peninggalan pusaka. Teknik pada produk ini adalah Kasab pesisir selatan dan pesisir timur Aceh. Ukuran 38 dengan ketinggian hak $8 \mathrm{~cm}$, jenis sepatu wedges shoes midle booths inform oval D'orsay. Bahan upper yang digunakan yaitu denim, benang jahit denim, tali cord, tali elastis, benang bordir.

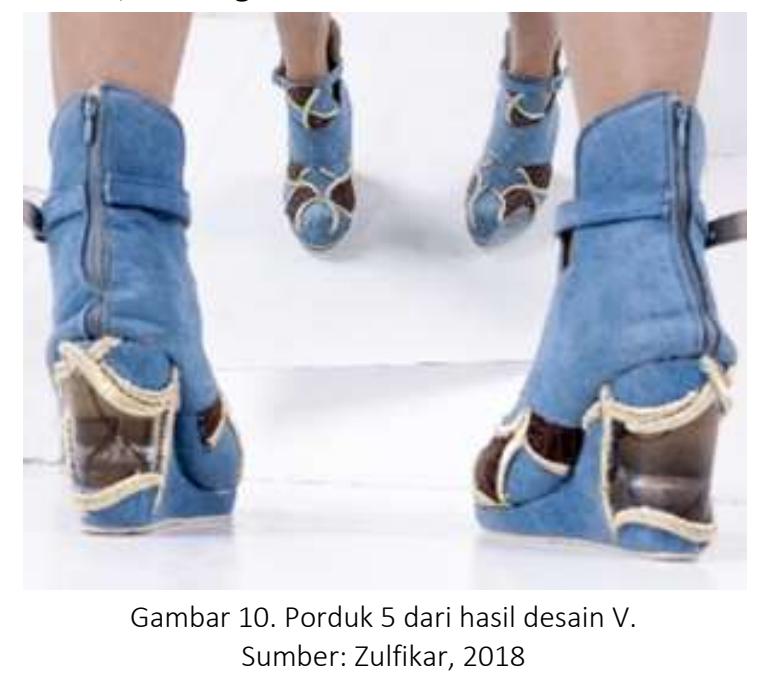

\section{PENUTUP}

Perancangan produk sepatu kasual ini dilandasi oleh permasalahan bagaimana penerapan Kasab tradisi Aceh sebagai teknik dalam perancangan desain tekstil permukaan pada produk sepatu wanita dewasa? Dari pertanyaan dan hasil dapat disimpulkan sebagai berikut:

Produk sepatu dengan penerapan teknik Kasab secara visual memiliki keunikan dan ciri khas tersendiri. Pengembangan motif secara kontemporer dengan arahan aspek estetis munculkan suatu kebaharuan. Motif utama dan motif pendukung dikembangkan untuk menyesuaikan bahan upper sepatu. Penyesuaian tersebut berhasil dilakukab dengan cara menerapkan teknik Kasab pesisir timur dan pesisir selatan Aceh. Bahan tersebut diaplikasikan pada sepatu kasual edgy style untuk wanita dewasa. Isen-isen didalam motif bersumber dari ide motif tradisional Aceh, sehingga perancangan ini dapat mempertahankan ciri khas tekstil tradisional. Potensi visual dari jahitan yang dikerjakan manual menjadi unsur etnik pada karya ini. Selain itu, adanya pertimbangan pada perancangan desain produk yaitu memikirkan efek visual yang tercipta dari bahan denim. Bahan tersebut meggambarkan sebuah produk yang kasual. Benang emas sebagai sumber ide dari seuhab tradisional diganti dengan menggunakan benang katun, benang bordir, tali elastis, dan tali cord. Maka penerapan teknik, pengembangan motif, dan mencoba bahan baru pada karya ini dapat menjadi kekuatan desain yang mempunyai nilai pembeda dibandingkan dengan produk sepatu etnik yang sudah ada. Pengembangan desain produk sepatu etnik ditawarkan pada perancangan ini adalah memvisualsasi sepatu kasual edgy style wanita dewasa. Melalui penerapan teknik Kasab tradisi Aceh sebagai teknik pembuatan motif diatas permukaan kain untuk upper sepatu tersebut.

\section{DAFTAR PUSTAKA}

Affanti, T.Bina. (2008). Ornamentik. Buku panduan pembelajaran. Surakarta: Fakultas Sastra dan Seni Rupa Universitas Sebelas Maret.

Balai Pengembangan Industri Persepatuan Indonesia-BPIPI. (2017). "Teknis Teknologi Produksi Alas Kaki" Modul Bimbingan. Jakarta: Kementrian Perindustrian Republik Indonesia.

Budiyono. Dkk. (2008). Kriya Tekstil Jilid I. Jakarta: Direktorat Pembinaan Sekolah Menengah Kejuruan.

Harun, Mohd. dkk. (2016). Pendataan \& Inventarisasi Budaya Etnis di Aceh. Banda 
Aceh: Dinas Kebudayaan dan Pariwisata Aceh.

Leigh, Barbara (1989). Hands of Time The Craft of Aceh. Jakarta: Ikatan Penerbit Indonesia.

Mandasari, Rizky. (2017). 15 Istilah fashion. (https://brilistyle.brilio.net/info/15-istilahfashion-ini-kerap-muncul-tapi-tak-semuaorang-paham-artinya-170510q.html, diakses 27 oktober 2018).
Nurani, Lulu. (2013). Beauty and Pain (Kajian Sosioteknis Sepatu Hak Tinggi/Hight Heel pada Wanita). Jurnal Tugas Akhir. Bandung: Institut Teknologi Bandung.

Rizali, Nanang. (2012). Metode Perancangan Tekstil. Surakarta: Universitas Sebelas Maret Press. 